EUROPEAN SOCIETY FOR MICR

Tel.:

Fax:

E-Mail:

Main Research Interests (Key Words):

I agree to have my name, address and research interests published on the web site of the European Society for Microcirculation:

YES $\square \quad$ NO $\square \quad$ (If you don't tick here, we assume your agreement.)

Date:

Signature:

Applications must be supported either by sponsorship of two members of the European Society for Microcirculation or by submitting your CV with the application.

Sponsored by

and

Membership will be activated upon receipt of your payment.

The membership fee of the Society is $f 30.00$ payable every two years.

Payment Methods:

$\square$ Debit/Credit Card (not American Express or Diners)

Card No:

Expiry Date:

Issue number (if applicable):

$\square$ Cheque/Bank Draft in pounds payable to 'European Society for Microcirculation' $\square$ Money transfer ( $\mathrm{f} 37.00$ equivalent to cover additional bank charges) to our bank account \#00150472, Swiftcode RBOSGB2S, The Royal Bank of Scotland, Aberdeen Central Branch, 12 Golden Square, Aberdeen, AB9 8DU

Return this form to:

Prof. Dr. Angela C. Shore, Treasurer ESM

School of Postgraduate Medicine and Health Sciences

Barrack Road, Exeter, Devon, EX2 5AX, UK

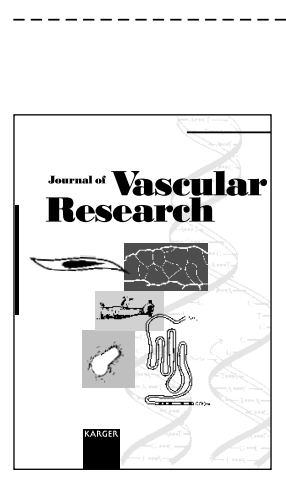

\section{Order Form}

Members of the Society are reminded of the generous discount available on subscriptions to our sponsored journal, the Journal of Vascular Research (incorporating International Journal of Microcirculation). The subscription rate for 2004 is CHF 94.- + 31.80 shipment costs / EUR 67.- + 22.80 shipment costs / USD $72.00+31.80$ shipment costs per year (6 issues).

$\square$ Please send me a specimen copy

$\square$ Please send me further information on JVR

$\square$ I would like to order JVR on the above mentioned terms

S. Karger AG, P.O. Box CH-4009 Basel (Switzerland)

Fax +4161306 1234

Karger Publishers, Inc.

P.O. Box 529

Farmington, CT 06085 (USA)

Fax (860) 675-7302

\section{Payment:}

$\square$ Check enclosed $\quad \square$ Please bill me

$\square$ Credit Card

Card No:: Exp. date:

Name/Address (please print):

Date/Signature: 